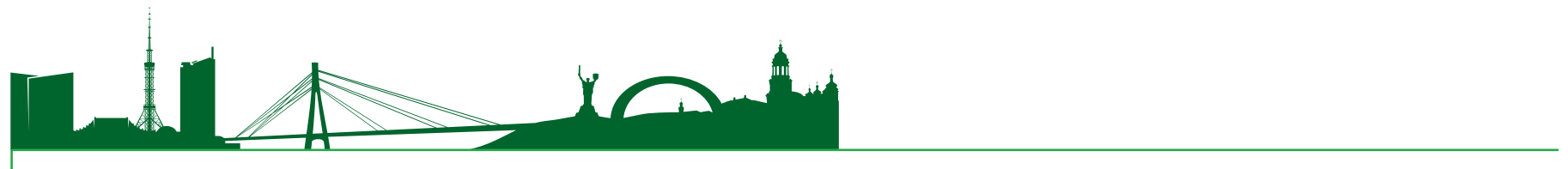

УДК 625.745.1

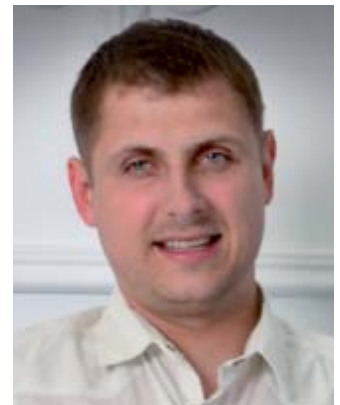

ГОАОВКО Р.О.

Зав. лаб., ДП «Державний науково-дослідний інститут будівельних конструкцій», м. Київ, Україна, e-mail: golovko@ndibk.qov.ua, тел.: + 38 (050) 415-33-87, ORCID: 0000-0003-4821-0704

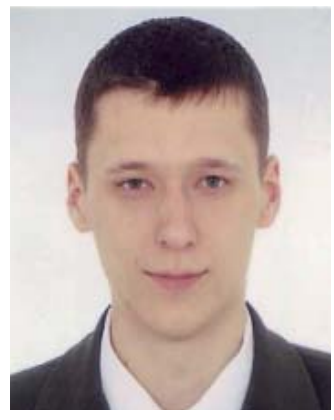

ЗЕЛЕНКО С.В.

Ст. науковий співробітник, ДП «Державний науководослідний інститут будівельних конструкцій», м. Київ, Україна, e-mail: euzelenko@gmail.com, тел.: + 38 (044) 249-37-34, ORCID: 0000-0002-9032-2577

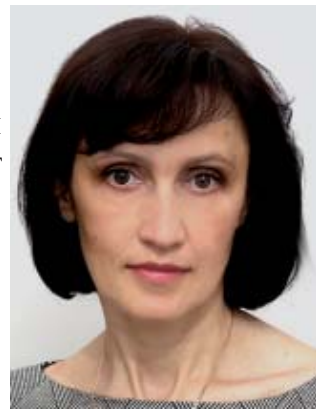

ДУБОВИК С.О.

Провідний інж., ДП «Державний науково-дослідний інститут будівельних конструкцій», м. Київ, Україна, e-mail:dubovik@ndibk.qov.ua, тел.: + 38 (044) 249-38-21, ORCID: 0000-0002-8564-0693

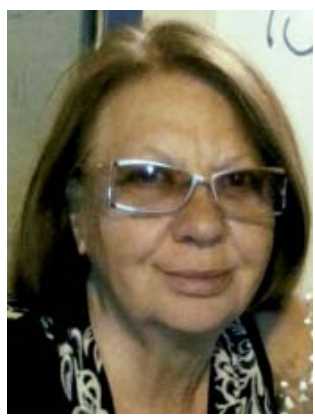

\section{КОАУМБЕТ $\Lambda . В$.}

Провідний інж., ДП «Державний науково-дослідний інститут будівельних конструкцій», м. Київ, Україна, e-mail: kol@ndibk.qov.ua, тел.: + 38 (044) 249-37-81, ORCID: 0000-0002-7887-9188

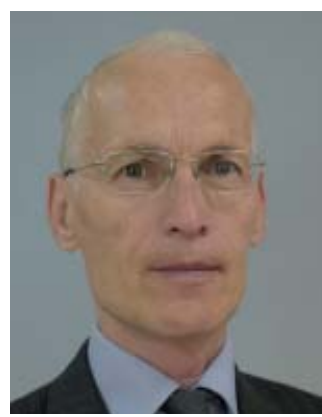

\title{
АІСЕНИЙ О.М
}

Канд. технічних наук, зав. відділу, ДП «Державний науково-дослідний інститут будівельних конструкцій», м. Київ, Україна, e-mail: lab343@ndibk.qov.ua, тел.: + 38 (050) 415-34-83, ORCID: 0000-0003-0792-8082

\section{КОМПАЕКСНЕ ДОСЛІДЖЕННЯ ТЕХНІЧНОГО СТАНУ КОНСТРУКЦІЙ МОСТУ ЧЕРЕЗ Р. ДЕСЕНКУ В М.КИЕВІ}

\section{АНОТАЦІЯ}

Викладено основні результати комплексного спеціального обстеження мосту через р. Десенку в м. Києві, що входить до комплексу споруд Північного мостового переходу і забезпечує транспортне з'єднання лівого та правого берегів Дніпра у північній частині міста. Міст експлуатується понад 40 років. Конструкції мосту, окрім прямого призначення, використовуються як опорні елементи для пропуску трубопроводів водогону та теплопостачання.

При комплексному обстеженні виявлено численні пошкодження залізобетонних опор, конструкцій прогонових будов та кінцевих ділянок, а також опорних металевих конструкцій в міжбалочному просторі. Перевірні розрахунки несучої здатності та вантажопідйомності елементів мосту з урахуванням зафіксованих дефектів і по- шкоджень, а також визначення залишкового ресурсу конструкцій мосту показали, що міст придатний до подальшої експлуатації: загальний експлуатаційний стан категорії 4 - «обмежено працездатний».

Частина елементів конструкцій мосту потребує капітального ремонту відповідно до спеціально розробленого проекту при обов'язковому науковотехнічному супроводі як проекту, так і ремонтних робіт. Також є необхідність у забезпеченні циклічних спостережень за станом конструкцій мосту.

КАЮЧОВІ СЛОВА: міст, нерозрізна прогонова будова, попередне напруження канатами, коробчаста балка, клеєні стики.

FULL-SCALE SURVEY OF THE STRUCTURAL CONDITION OF THE BRIDGE ACROSS THE DESENKA RIVER IN KYIV 
HOLOVKO R.O. Laboratory head, State enterprise «State Research Institute of Building Constructions, Kyiv, Ukraine, e-mail: golovko@ndibk.qov.ua, tel.: + 38 (050) 415-33-87, ORCID: 0000-0003-4821-0704

DUBOVYK S.O. Lead eng., State enterprise «State Research Institute of Building Constructions»,

Kyiv, Ukraine,

e-mail: dubovik@ndibk.qov.ua,

tel.: + 38 (044) 249-38-21,

ORCID: 0000-0002-8564-0693

ZELENKO Ye.V. Senior Researcher, State enterprise «State Research Institute of Building Constructions», Kyiv, Ukraine,

tel.: + 38 (044) 249-37-34,

ORCID: 0000-0002-9032-2577

KOLUMBET L.V. Lead eng., State enterprise «State Research Institute of Building Constructions»,

Kyiv, Ukraine,

e-mail:kol@ndibk.qov.ua,

tel.: + 38 (044) 249-37-81,

ORCID: 0000-0002-7887-9188

LISENYI O.M. PhD, Head of Department, State Enterprise "State Research Institute of Building Constructions",

Kyiv, Ukraine,

e-mail: lab343@ndibk.gov.ua,

tel.: +38 (050) 415-34-83,

ORCID: 0000-0003-0792-8082

\section{ABSTRACT}

There are the main results of the full scale survey of the bridge across the Desenka river in Kyiv, which is a part of the Northern bridge structures and provides transport connection of the right and the left banks of the Dnieper river in the northern part of the city. The bridge has being operated for more than 40 years. The bridge structures besides the designated purpose are used as bearing elements for water and heat pipes.

While the full scale survey a number of damaged reinforced concrete elements, continuous arm, end areas and supporting steel structures were found. Checking calculations of the bearing capacity and the live load capacity of the bridge considering the recorded defects and damages and the calculation of the bridge residual life shows that the bridge is serviceable for continued operation, i.e. category 4 general operating condition meaning partially incapacitated.

A part of bridge elements needs major repairs according to a specially developed project under scientific and technical support of the project itself and the repair works. There is a need in cyclic monitoring of the bridge structures also.

KEY WORDS: bridge, reinforced concrete structures, continuous anchor arm, rope prestressing, hollow beam, glued joints.

\section{ВСТУП}

Міст через річку Десенку, що входить до комплексу споруд Північного мостового переходу у місті Києві, був введений в експлуатацію в 1974 р.

Комплексне дослідження мосту виконане у жовтні-грудні 2017 року.

\section{АНАЛІЗ ДЖЕРЕА ІНФОРМАЦІЇ}

Перед виконанням роботи були вивчені робочі креслення мосту через р. Десенку, виконані Київською філією інституту «Союздорпроект» в 1970-1974 роках, а також звіти про попередні обстеження мосту, що проводилися у 19982003 роках. Зазначені матеріали зберігаються в експлуатуючій організації КП «Київавтошляхміст».

В узагальнюючому звіті [1] відмічено, що конструкція мосту через р. Десенку була піонерною у радянському мостобудуванні. При його будівництві освоєні, як елементи нової техніки, методи виготовлення і монтажу попередньо напруженої прогонової будови з коробчастих збірних блоків та технологія їх об'єднання у нерозрізну систему.

Відомо, що на час будівництва мосту через p. Десенку у м. Києві аналогічні конструкції залізобетонних попередньо напружених прогонових будов мостів з коробчастих збірних блоків на клейових стиках широко застосовувались у мостовому будівництві Франції, ФРН, Великобританії, Нідерландів, Італії, Чехословаччини та інших країн [2].

Напружене армування нерозрізної прогонової будови мосту через р. Десенку запроектоване у відповідності з посібником [3], що був складений в СоюздорНИИ. У цьому посібнику висвітлені питання конструювання і технології серійного виготовлення конусних анкерів для пучків арматурних канатів діаметром 15 мм, технологія виготовлення і натягування пучків канатів. Досвід, набутий при проектуванні і зведенні мосту через р. Десенку, був узагальнений при складанні технічних вказівок щодо проектування, виготовлення та монтажу складених по довжині конструкцій залізобетонних мостів ВСН 98-74 (Минтрансстрой CCCP) [4].

3 публікацій в мережі Інтернет відомо, що в наступні роки після зведення мосту через р. Десенку за аналогічною технологією у СРСР був зведений ряд мостів і шляхопроводів. Зокрема, коробчасті елементи прогонової будови з клейовими стиками застосовані в конструкціях прогонової будови Південного мосту в м. Києві та Кайдацького мосту в м. Дніпро. 
У кінці 1980-років були проведені експериментальні дослідження клейових стиків, їх результати викладені у дисертаційних роботах М.Е. Мохаммад [5] і В.В. Брауна [6]. У цих роботах розглянуті умови несучої здатності стиків при різних видах напруженого стану, в тому числі при тривалому навантаженні, відмічені недоліки методів розрахунку стиків, що наведені у нормах.

3 роботи [5] відомо також про аварійну ситуацію 3 частковим руйнуванням нерозрізної прогонової будови мосту з клейовими стиками через р. Сухону в м. Великий Устюг, що мала місце в 1980-х роках. Не виключено, що ця аварійна ситуація спонукала до проведення детального обстеження конструкцій мосту через р. Десенку спеціалістами СоюздорНИИ в 1989 р. Посилання на таке обстеження міститься у звіті [1], проте самі звітні матеріали 1989 р. не виявлені.

\section{МЕТА ДОСАІДЖЕННЯ}

Метою комплексного дослідження мосту через р. Десенку в м. Києві є обгрунтування та надання вихідних даних для розробки проекту капітального ремонту на основі результатів дослідження технічного стану, несучої здатності та залишкового ресурсу його елементів.

\section{ЗАДАЧІ ДОСАІДЖЕННЯ}

Задачі дослідження поділялись на такі групи.

1. Натурне візуальне обстеження елементів мосту: коробчастих та плитних елементів прогонової будови, опор та опорних частин, елементів мостового полотна, конструкцій кінцевих ділянок мосту, опорних конструкцій комунікацій, підходів та регуляційних споруд, складання схем розташування пошкоджень, узагальнення в табличному виді обсягів пошкоджень.

2. Спеціальні та інструментальні дослідження: підводне водолазне обстеження руслових опор, вимірювання глибин підмостового русла 3 побудовою профілів поздовжніх та приопорних морфостворів, визначення міцності бетону, тести на глибину карбонізації бетону, визначення ступеню корозії та втрати площі перерізу арматури, вибіркові випробування цілісності клейових стиків ультразвуковим методом, нівелювання прогонової будови та мостового полотна.

3. Розрахункові оцінки: вантажопідйомності прогонової будови $з$ врахуванням пошкоджень, експлуатаційного стану елементів прогонової будови за показниками технічного стану, вантажопідйомності та за рейтингом прогонової будови в цілому, розрахунки залишкового ресурсу елементів мосту та споруди в цілому.

4. Визначення причин пошкоджень та складання рекомендацій щодо складу робіт 3 капітального ремонту мосту.

5. Визначення складу робіт з моніторингу i науково-технічного супроводу проектування та виконання ремонтних робіт.

\section{ЗАГАЛЬНА ХАРАКТЕРИСТИКА МОСТУ}

На рис. 1 показано загальний вигляд мосту через р. Десенку, на рис. 2 і 3 - схеми основних конструктивних рішень. Міст зведено із застосуванням двох конструктивних систем. Прогонову будову мосту між опорами 0 і 12 утворює нерозрізна дванадцятипрогонова попередньо напружена балка зі збірно-монолітного залізобетону загальною довжиною 730,8 м (рис. 2 а). Крім того, до складу мосту входять дві, так звані, кінцеві ділянки, прогонову будову яких утворюють розрізні плити настилу довжиною 15 м і 6 м (рис. 3).

Геометрична схема мосту - 12 нерозрізних прогонів 50,4 м + 10×63,0 м + 50,4 м; крім того, лівобережна і правобережна кінцеві ділянки по схемі 15,0 м + 6,4 м; повна довжина споруди 778,48 м.

Нерозрізна коробчаста прогонова будова по довжині мосту складена з повторюваних збірних елементів (блоків) заводського виготовлення (рис. 4). Коробчасті блоки прогонової будови по довжині з'єднані клеєними стиками та обтиснені пучками сталевих канатів 3 12-ти семидротових пасм $\varnothing 15$ мм. Попередньо напружені пучки канатів мають довжину від 10 до 63 м і розташовані всередині стінок, днища та вутів коробчастих елементів у закритих каналах діаметром 90 мм.

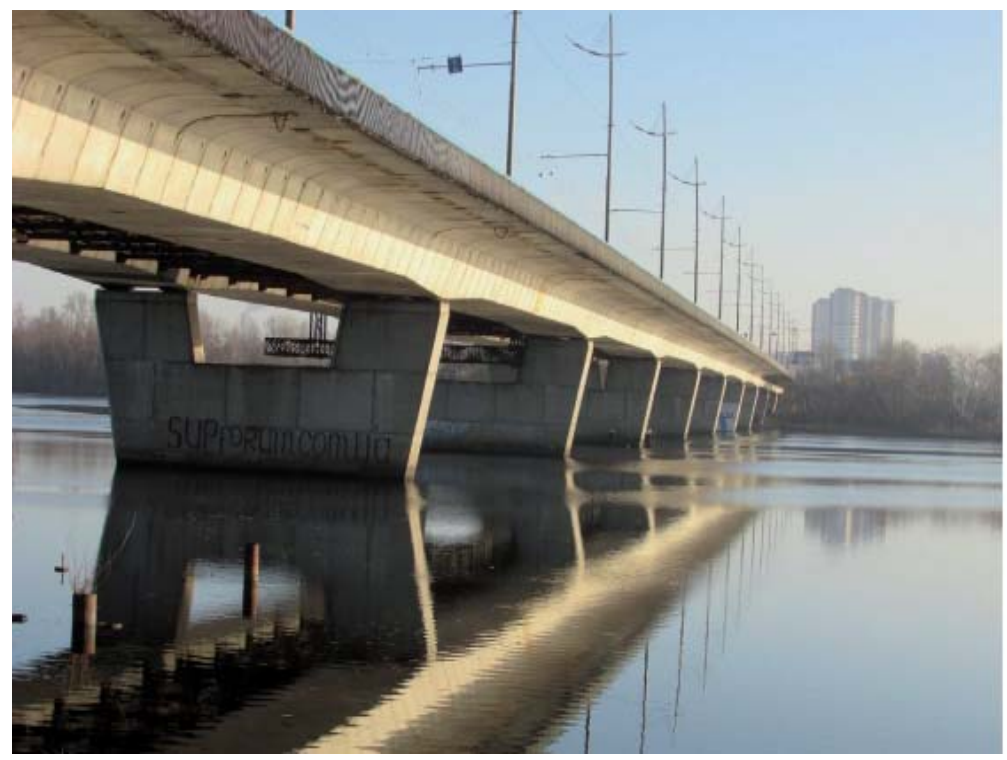

Рис. 1. Загальний вигляд мосту (вид 3 правого берега) 


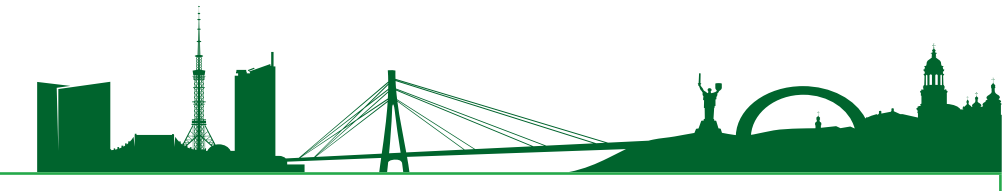

a-1) Лівобережна

кінцева ділянка

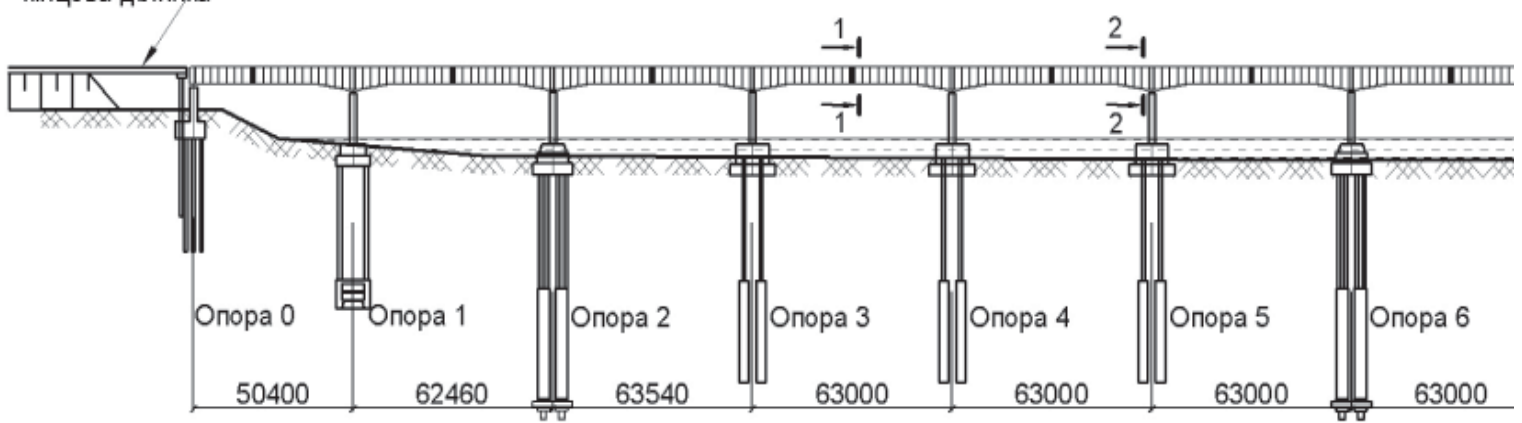

Нерозрізна прогонова будова

Правобережна кінцева ділянка

a-2)

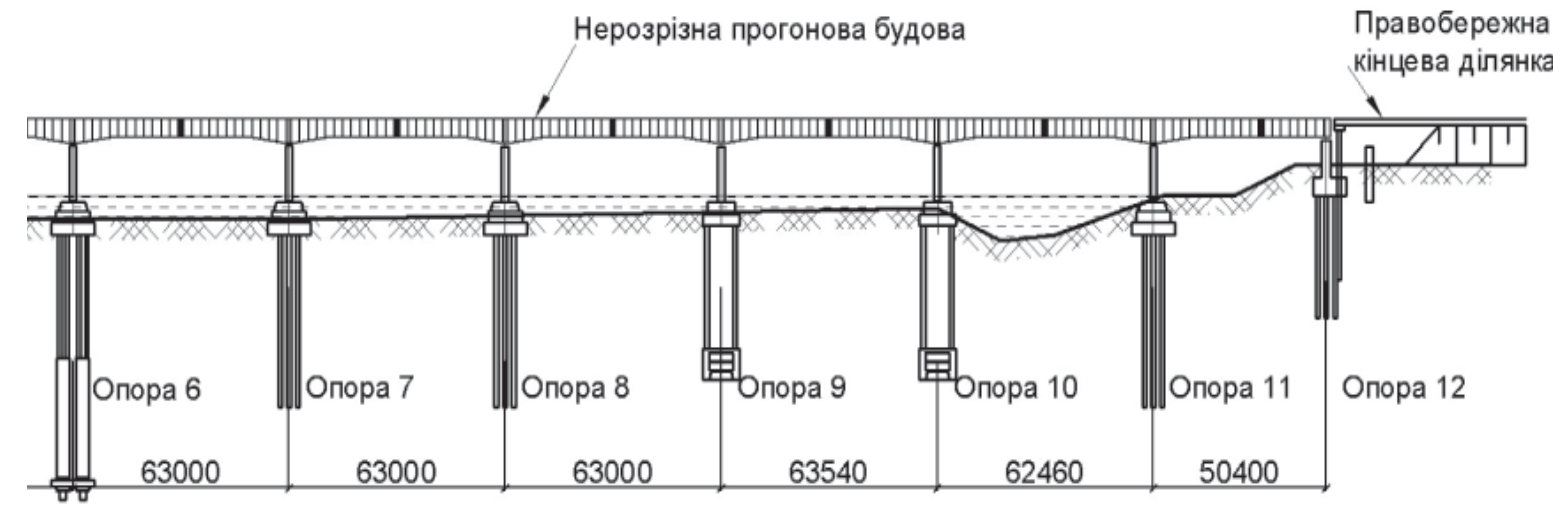

6)

$1-1$

2-2
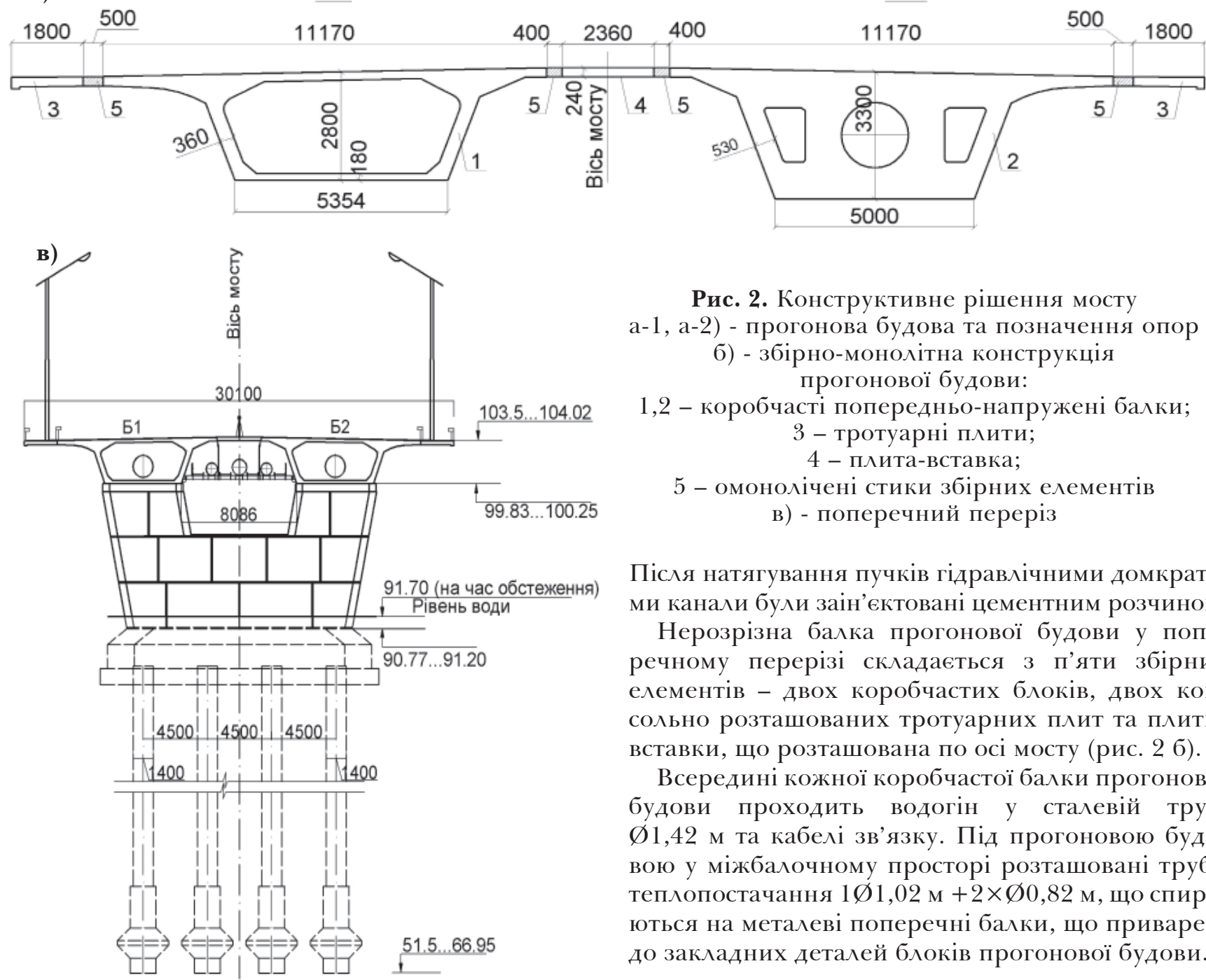

Рис. 2. Конструктивне рішення мосту a-1, a-2) - прогонова будова та позначення опор б) - збірно-монолітна конструкція прогонової будови:

1,2 - коробчасті попередньо-напружені балки; 3 - тротуарні плити; 4 - плита-вставка;

5 - омонолічені стики збірних елементів в) - поперечний переріз

Після натягування пучків гідравлічними домкратами канали були заін'єктовані цементним розчином.

Нерозрізна балка прогонової будови у поперечному перерізі складається 3 п'яти збірних елементів - двох коробчастих блоків, двох консольно розташованих тротуарних плит та плитивставки, що розташована по осі мосту (рис. 2 б).

Всередині кожної коробчастої балки прогонової будови проходить водогін у сталевій трубі $\varnothing 1,42$ м та кабелі зв'язку. Під прогоновою будовою у міжбалочному просторі розташовані труби теплопостачання $1 \varnothing 1,02$ м $+2 \times \varnothing 0,82$ м, що спираються на металеві поперечні балки, що приварені до закладних деталей блоків прогонової будови. 


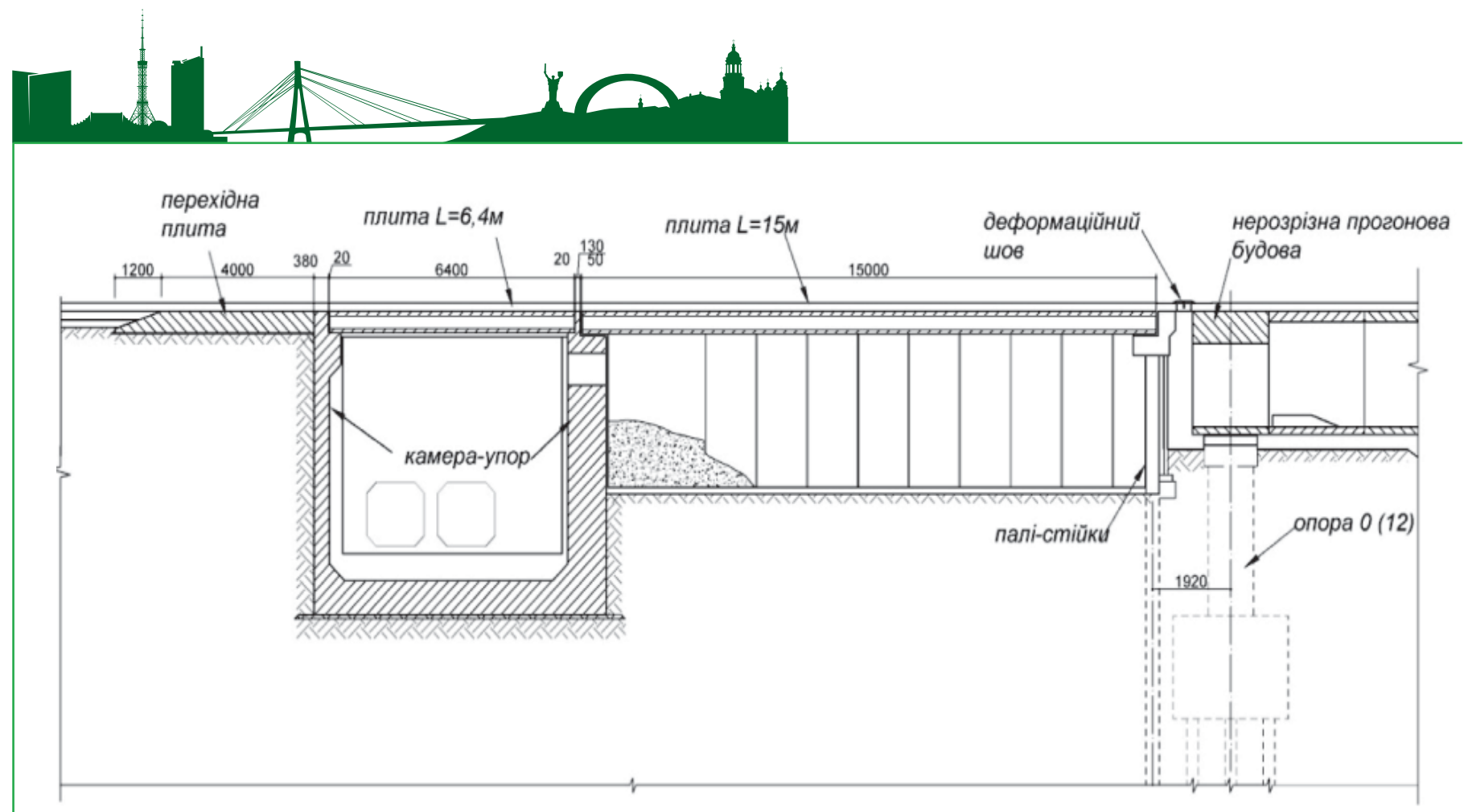

Рис. 3. Схема конструктивного рішення кінцевої ділянки мосту

a)

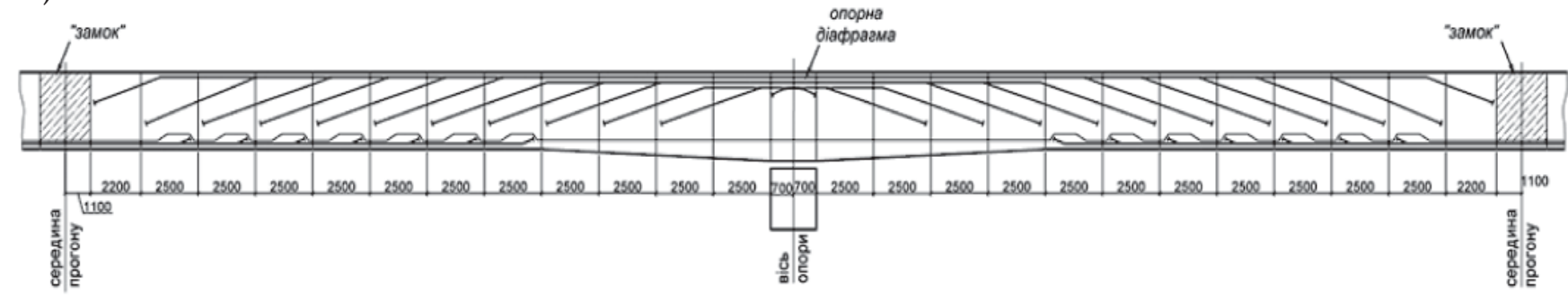

6)

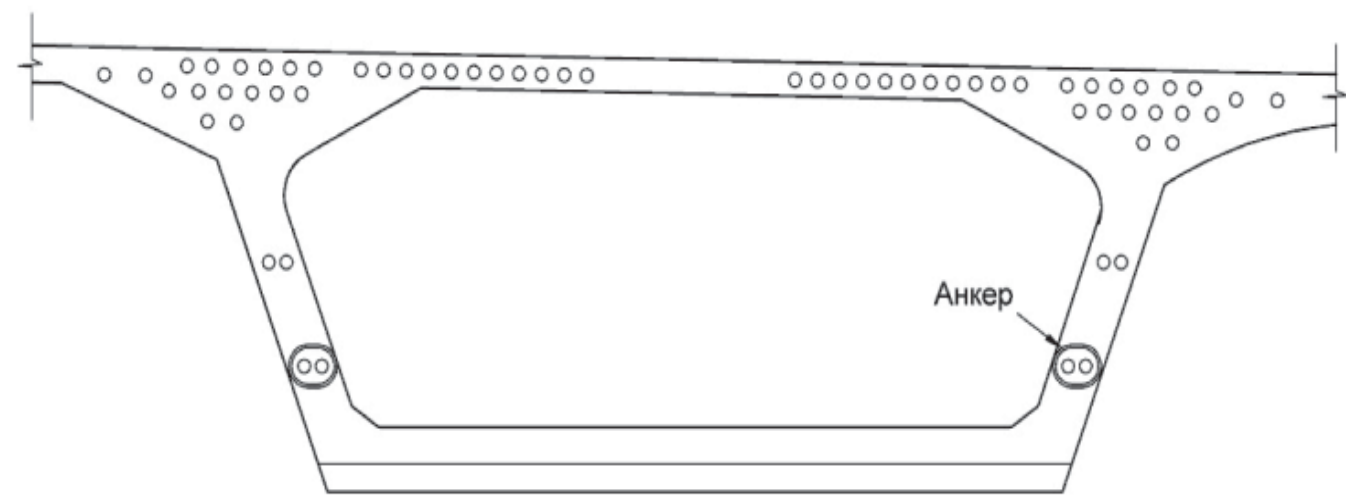

Рис. 4. Схема компонування нерозрізної прогонової будови (а) та розміщення попередньо напружених пучків над опорою (б)

Нерозрізна коробчаста прогонова будова мосту спирається на два кінцеві стояни (устої) та на 11 проміжних опор, 8 з яких розташовані в руслі річки, а 3 - на суходолі (рис. 2 а). Монолітні залізобетонні ростверки проміжних опор влаштовані на штучних основах у вигляді: бурообсадних залізобетонних стовпів у металевих трубах (опори 3 і 5), збірних залізобетонних пальоболонок (опори $2,4,6,7,8,11$ ), на опускних колодязях (опори 1, 9, 10). Стояни (опори 0 і 12) влаштовані на пальовій основі $з$ попередньо напружених паль.

Опори масивні збірно-монолітні з розмірами в плані 1,30 м×19,16 м (рис. 2 в). Опалубкою опор є пустотілі збірні просторові залізобетонні елементи 3 товщиною стінки 0,3 м. У внутрішній порожнині опори, що утворена пустотілими блоками, влаштована серцевина опори з монолітного залізобетону.

Нерозрізна балочна прогонова будова мосту має гумові опорні частини: нерухомі - на опорі 6; рухомі в поздовжньому напрямі - на інших опоpax.

На правому i лівому берегах розташовані кінцеві ділянки мосту (рис. 3), що включають перехідні прогони та монолітні залізобетонні камери-упори, що призначені для монтажу та обслуговування трубопроводів. Кінцеві ділянки 




перекриті шарнірно опертими балочними плитами довжиною 15 м і 6,4 м. Плити довжиною 15 м спираються на стіну камери-упора та на ригель рамної опори.

Деформаційні шви нерозрізної прогонової будови влаштовані на опорах 0 і 12. Деформаційні шви мають конструкцію перекритого типу з плаваючими ковзними металевими пристроями та притискними пружинними пристроями. Крім того, влаштовані деформаційні шви розрізних плит настилу кінцевих ділянок мосту над стінками упорних камер.

\section{РЕЗУАЬТАТИ НАТУРНОГО ОБСТЕЖЕННЯ}

Комплексне натурне обстеження конструкцій мосту виконане 3 метою виявлення елементів, що потребують ремонту, посилення та/або заміни, а також для визначення орієнтовних обсягів ремонтних робіт. В залежності від наявних пошкоджень, технічний стан елементів мо-

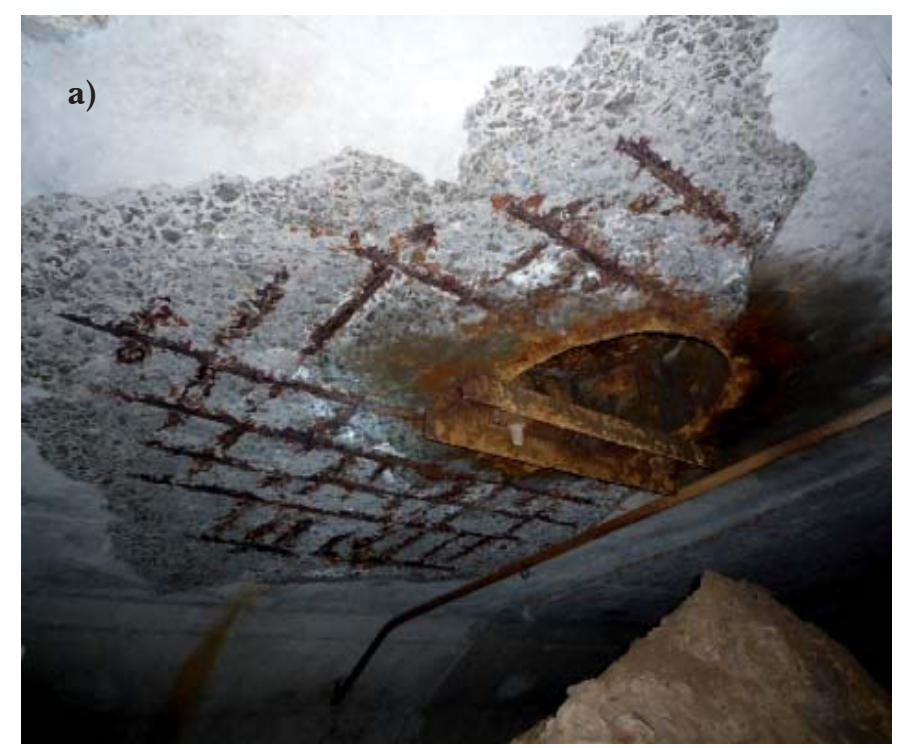

Рис. 5. Руйнування захисного шару бетону, оголення і корозія арматури верхньої (а) та нижньої (б) плит коробчастої балки
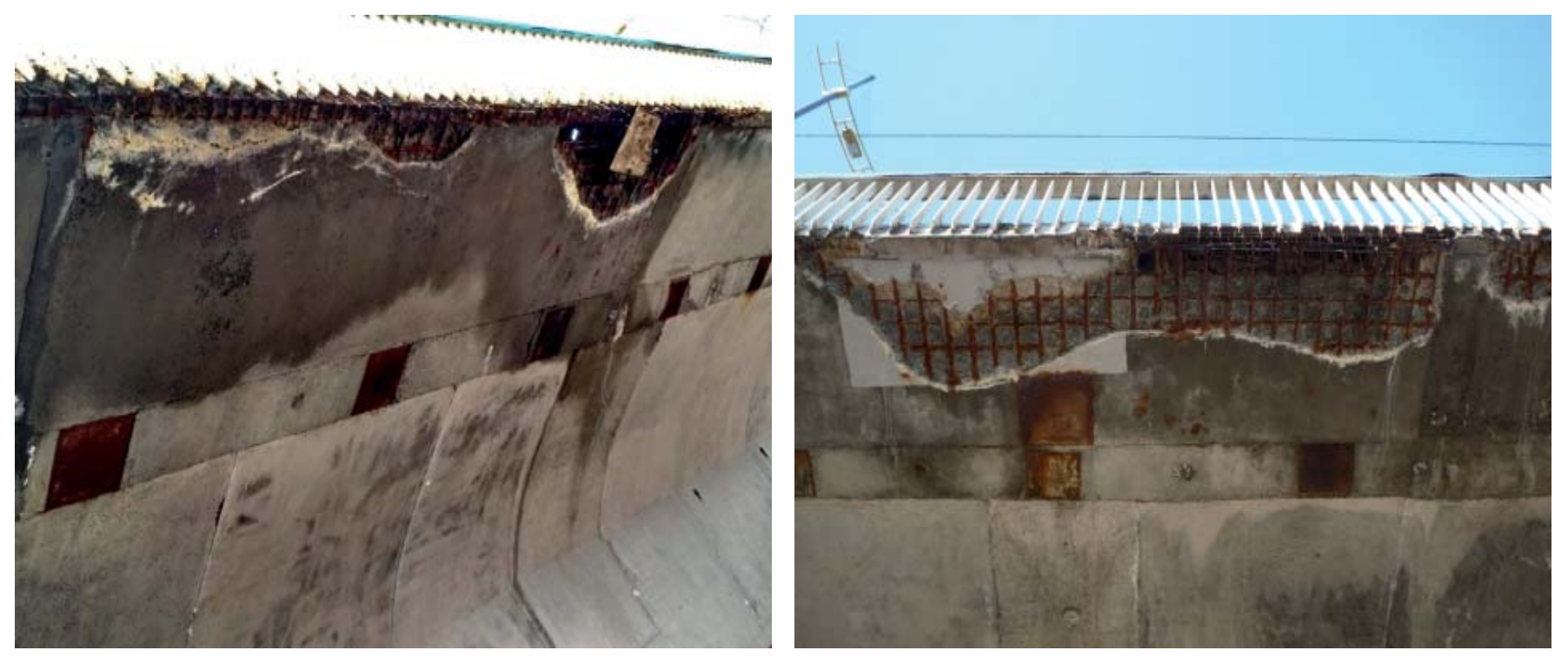

Рис. 6. Пошкодження тротуарних плит (вид знизу) 



Рис. 7. Силові (а) та корозійні (б) пошкодження вузлів анкерування напружених арматурних пучків нижньої плити коробчастих балок

Експлуатаційний стан коробчастих балок прогонової будови в цілому відповідає категорії 3 «працездатний», при цьому окремі ділянки верхньої і нижньої плит мають стан 4 «обмежено працездатний». Консольні плитні звіси прогонової будови перебувають у стані 5 «непрацездатний» внаслідок руйнування плити на значній площі.

При візуальному обстеженні надводної частин опор виявлено сліди замокання поверхні опор через люки у плиті проїзної частини; сліди вилуговування, вертикальні тріщини на поверхні всіх проміжних опор 3 шириною розкриття до 3 мм, механічні виколи бетону, руйнування бетону швів між блоками збірно-монолітних опор, пошкодження проявляються на межі підводної та надводної частин опор в зоні заморожування-розморожування водонасиченого бетону. Порівняно невеликі пошкодження виявлені при підводному водолазному обстеженні руслових опор. Місцеві розмиви дна русла нижче підошви ростверка пальової основи опор складають від 0,3 м до 1,0 м.

Пошкодження опор відповідають категоріям експлуатаційного стану 2-3. Приклади пошкоджень надводної та підводної частини опор наведено на рис. 8 і 9.

Вперше з початку експлуатації мосту було проведено візуальне обстеження опорних частин балок на проміжних опорах. Ковзні елементи опорних частин закриті з усіх сторін ковзаючими гумовими ущільнювачами. Ознаки рухомості опорних частин та величини їх зміщень можна оцінювати за видимими слідами переміщень гумових ущільнювачів по поверхні піддону. Це дає підстави вважати, що рухомі опорні частини прогонової будови до цього часу відповідають своєму проектному призначенню. В окремих опорних частинах нерозрізної прогонової будови мосту було виявлено розтріскування та руйнуван-



Рис. 8. Сліди замочування, руйнування захисного шару бетону та тріщини на надводній частині опори



Рис. 9. Розмив пальової основи опори 


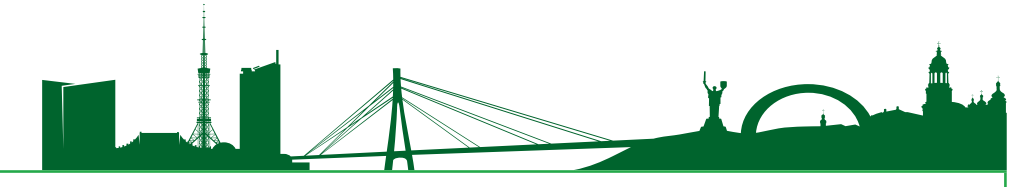

та прогоновою будовою, пошкодження ковзних гумових ущільнювачів. В опорних частинах, що розташовані на устоях (опори 0 і 12), виявлена пластова корозія металевих елементів опорних частин, засмічення ковзної поверхні продуктами корозії. Експлуатаційний стан опорних частин 2-3, на опорах 0, 10 і 12 - стан 4. Приклади пошкоджень опорних частин показано на рис. 10 і 11.

Основні елементи мостового полотна (покриття проїзної частини, тротуарів, бар'єрного і перильного огородження) зношені, мають значну кількість пошкоджень. Деформаційні шви прогонової будови розладнані, а їх пошкодження несумісні 3 можливістю сезонного регулювання. Стан зазначених елементів відповідає категорії 4 - «обмежено справний».

Водовідведення 3 мостового полотна



Рис. 10. Деформації гумових ущільнювачів в опорній частині опори № 1

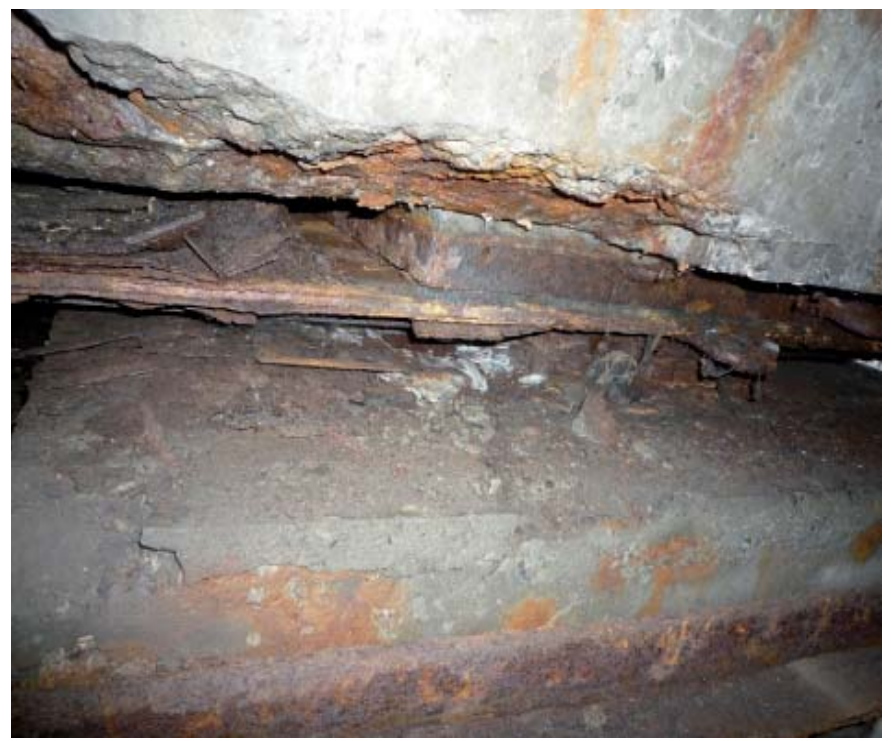

Рис. 11. Пластова корозія металевих пластин; засмічування ковзної поверхні опорної частини; виколи бетону на опорі 0 відбувається неорганізовано через звіси тротуарних плит. Тому крайові ділянки цих плит, а в деяких місцях - значна площа нижньої поверхні, мають корозійні пошкодження, місцями - до наскрізного руйнування бетону (рис. 6). Не забезпечується надійна гідроізоляція попередньо напружених коробчастих балок прогонової будови внаслідок протікань через негерметичні люки у верхній плиті (рис. 5), замочуються конструкції, прилеглі до опор 0 і 12, внаслідок руйнування лотків у деформаційних швах. Стан водовідведення та гідроізоляції віднесено до категорії 5 - «непрацездатний».

Залізобетонні конструкції кінцевих ділянок мосту мають значні корозійні пошкодження арматури та руйнування захисного шару бетону внаслідок незадовільної гідроізоляції і систематичного замокання. Особливо небезпечними є значне зменшення перерізу арматури плит настилу та паль-опор (рис. 12) і навіть руйнування частини стержнів робочої арматури в окремих попередньо напружених плитах настилу прольотом

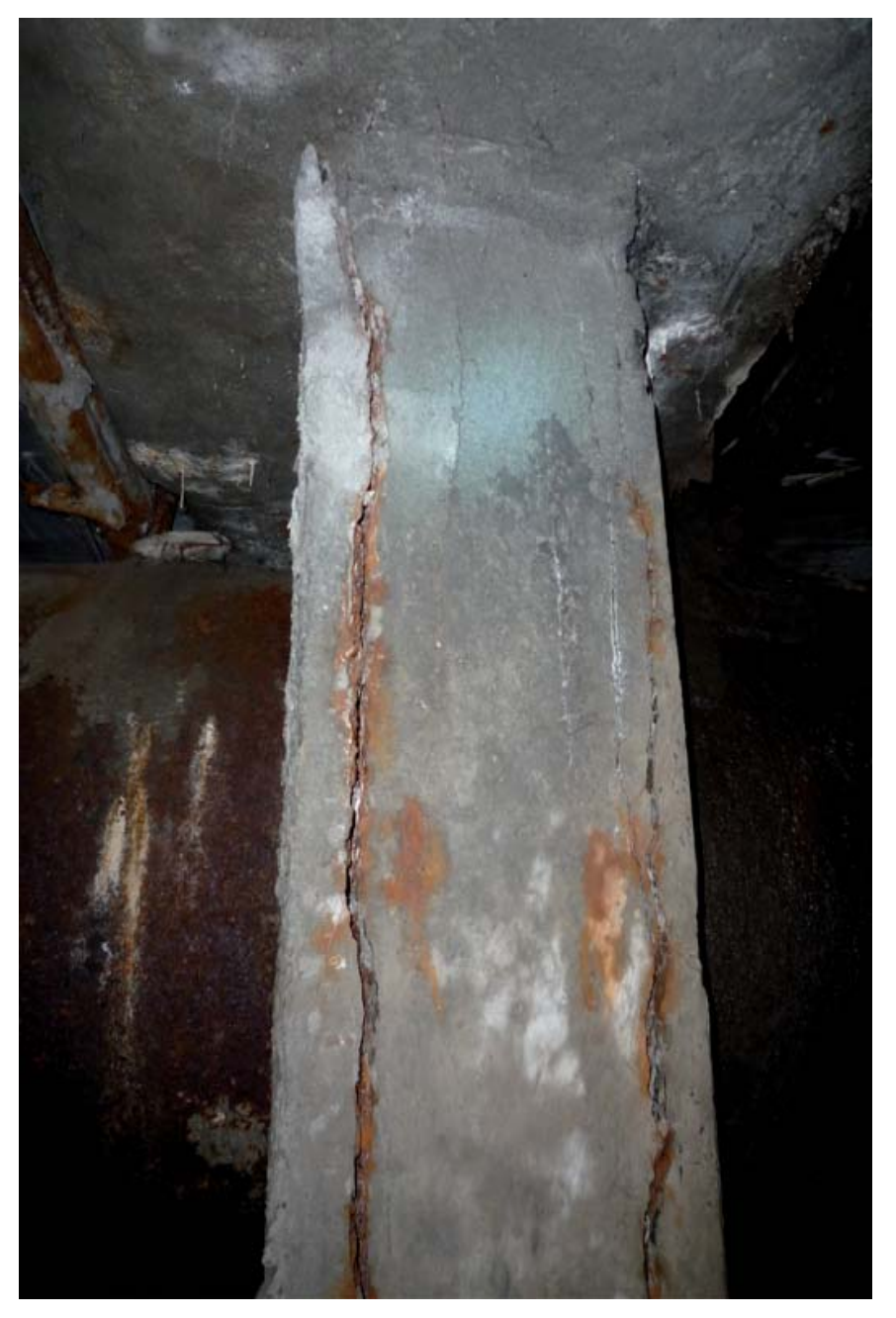

Рис. 12. Відшарування захисного шару, поздовжні тріщини у бетоні палі-стійки № 13 правобережної кінцевої ділянки 
15 м (рис. 13). Панелі стінового огородження мають випучування всередину кінцевих ділянок від тиску грунтової засипки (рис. 14). Ці пошкодження обумовлюють «обмежено працездатний» та «непрацездатний» стани елементів, зменшення розрахункової вантажопідйомності прогонової будови кінцевих ділянок мосту.

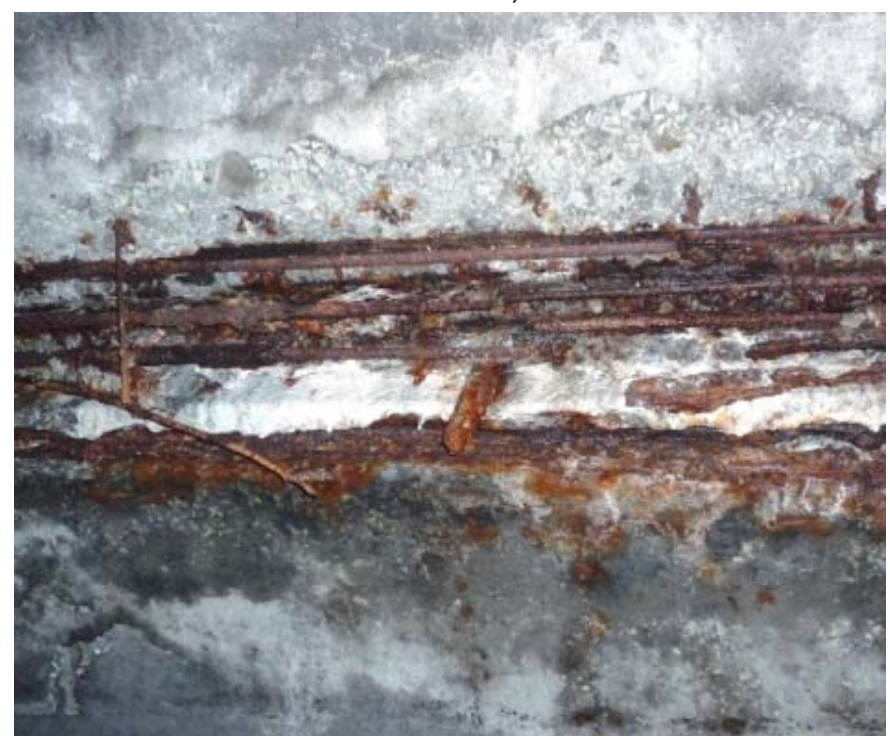

Рис. 13. Значне зменшення перерізу з розривом поздовжніх арматурних стержнів у плиті довжиною 15 м настилу правобережної кінцевої ділянки внаслідок корозії

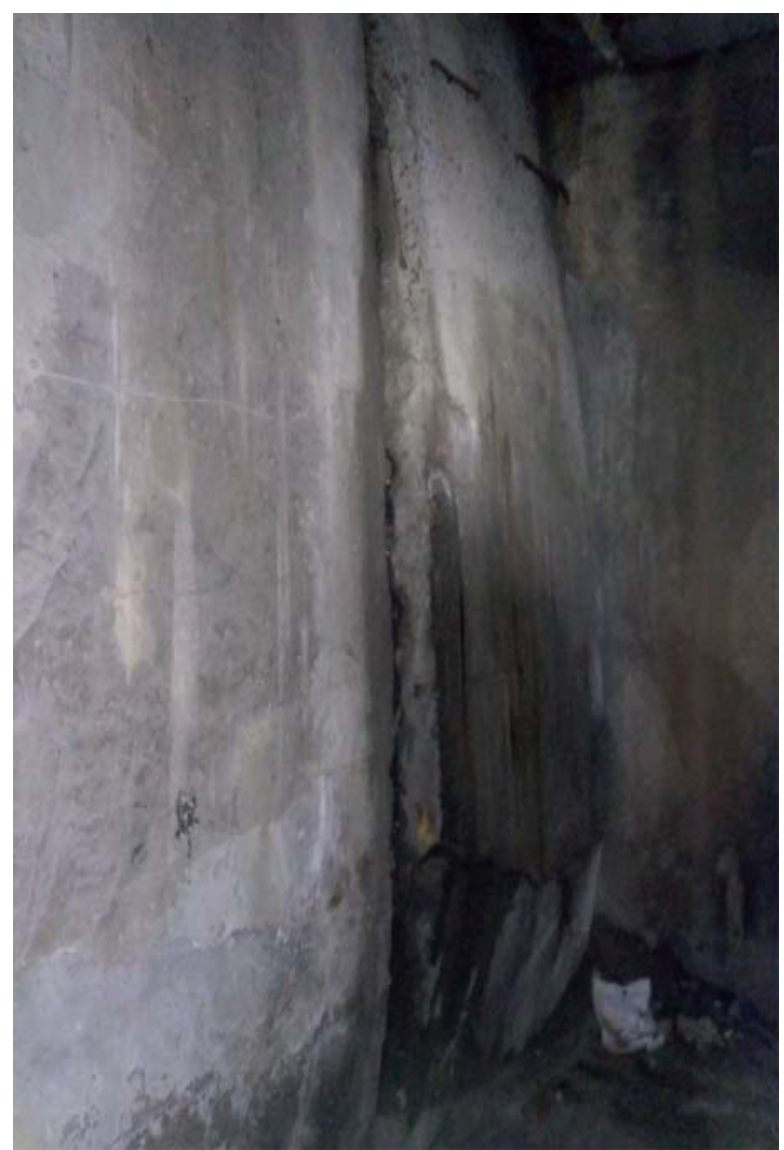

Рис. 14. Руйнування панелі стінового огородження правобережної кінцевої ділянки
Вперше за час 3 початку експлуатації мосту було виконано обстеження опорних металоконструкцій водонесучих комунікацій, що прокладені через міст. Значні корозійні ураження мають металеві конструкції опор комунікацій (рис. 15), конструкцій ходових містків та підвісних майданчиків. Причиною найбільш небезпечних корозійних пошкоджень і навіть руйнувань частини металевих опор трубопроводів $є$ постійне замочування елементів балок, трубопроводів та їх опор через люки у верхній плиті коробчастої прогонової будови. Експлуатаційний стан металевих опорних елементів визначено категорією 4 «обмежено працездатний».

\section{РЕЗУАЬТАТИ ДОСАІДЖЕНЬ}

За результатами неруйнівних випробувань фактичної міцності і однорідності бетону на стиск в конструкціях нерозрізної прогонової будови вияв-
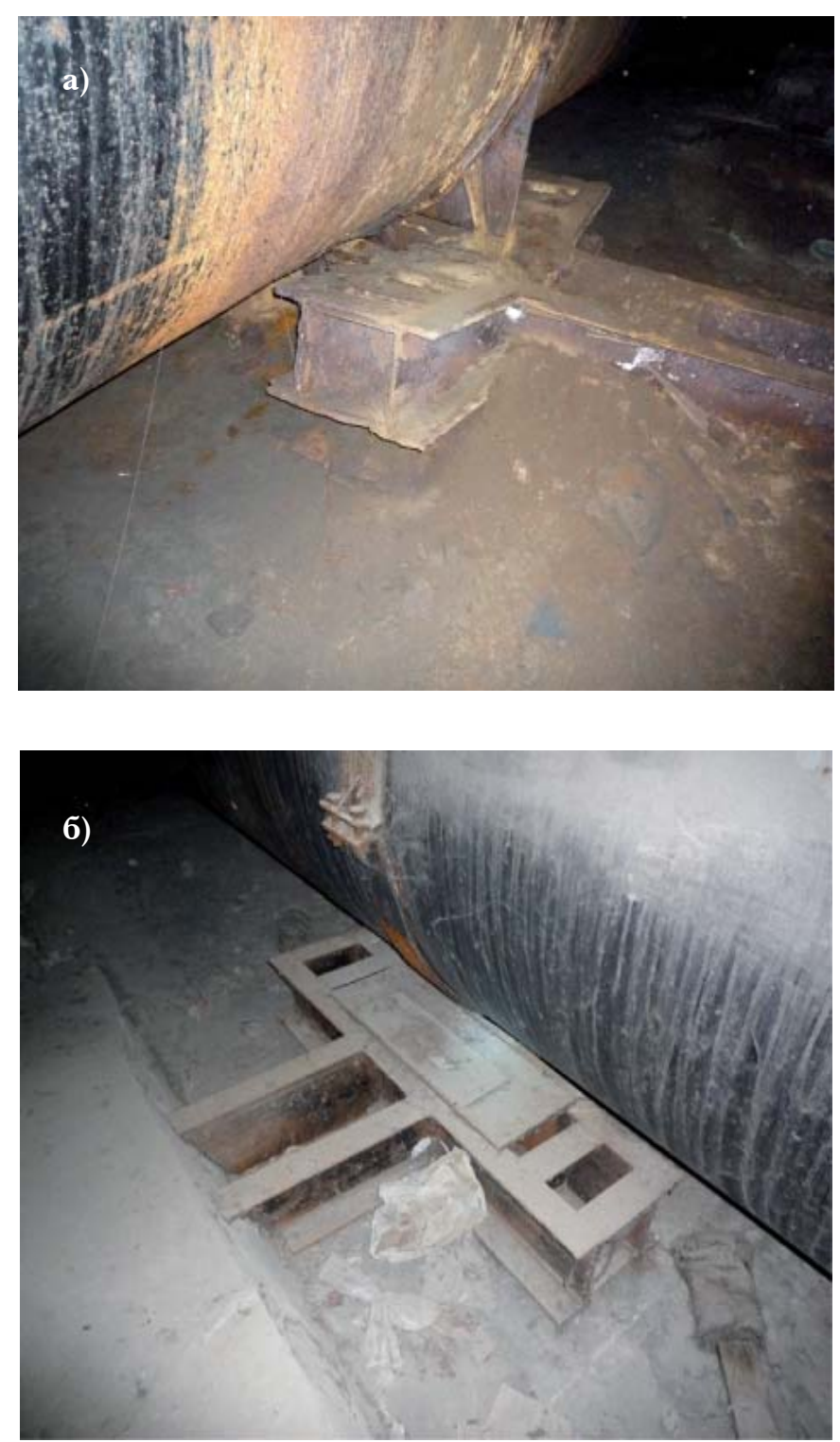

Рис. 15. Руйнування внаслідок корозії (a) та відсутність (б) опор водоводу 
лено, що фактичні коефіцієнти варіації міцності бетону в обстежених конструкціях перебувають в межах 6-8\%. Середня міцність бетону: в збірних коробчастих блоках балок Б1 і Б2 відповідає проектному значенню (С25/30), в збірних оболонках опор та в збірно-монолітних діафрагмах балок Б1 і Б2 вище від проектного значення (C25/30).

В конструкціях правобережної камери-упору коефіцієнти варіації міцності бетону в обстежених конструкціях знаходяться в межах 9-13\%; середня міцність бетону: в передній монолітній стіні - вище від проектного значення (С20/25), в збірних стійках (палях) та збірних плитах перекриття відповідає проектному значенню (С25/30), в збірних вертикальних плитах - нижче від проектного значення (C20/25).

Для забезпечення експлуатаційної придатності нерозрізної прогонової будови мосту важливим є забезпечення несучої здатності і довговічності клейових швів між блоками. Під час обстеження були зафіксовані локальні тріщини та несуцільне заповнення окремих швів. Виявлення тріщин у швах утруднене внаслідок засмічення і відсутності освітлення всередині прогонової будови. Тому, додатково до візуального обстеження, було застосовано інструментальний метод ультразвукової діагностики клейових швів. Такий метод був раніше розроблений в ДП НДІБК для оцінки якості заповнення епоксидним клеєм тріщин в залізобетонних конструкціях [8]. У результаті вибіркових випробувань клейових стиків не було зареєстровано суттєвих порушень цілісності приповерхневого шару клейових швів між збірними залізобетонними коробчастими блоками нерозрізної прогонової будови. Запропоновано в подальшому удосконалити методику ультразвукового дослідження та виконати суцільну діагностику клейових швів мосту.

Визначена глибина карбонізації бетону на непошкоджених ділянках конструкцій становить: в блоках прогонової будови - до 20 мм; в опорних частинах діафрагм - до 24 мм; в залізобетонних конструкціях правобережної кінцевої ділянки: плит настилу - до 17 мм, стінових панелей - до 14 мм, паль (опор) до 9 мм, ригелів - до 4 мм. Таким чином, поверхневий шар бетону залізобетонних конструкцій після більш ніж 50-річного періоду експлуатації не вичерпав захисних якостей по відношенню до арматури. Разом з тим, виявлені при обстеженні корозійні пошкодження арматури та захисного шару бетону конструкцій мосту відбуваються, як правило, на ділянках, що систематично замочуються внаслідок несправності гідроізоляції та недосконалості системи водовідведення.

Визначення ступеню корозії арматури здійснювалося на ділянках, де візуально було видно руйнування захисного шару бетону, шляхом вимірювання змін діаметру арматурного стрижня 3 подальшими розрахунками його площі перерізу. Ці дослідження показали, що втрати площі перерізу ненапруженої арматури блоків прогонової будови складають від 6\% до 18\%. Безпосередні пошкодження пучків канатної напруженої арматури прогонової будови не виявлені, проте небезпечною є корозія конструктивної арматури днища та обумовлене нею руйнування захисного шару бетону нижньої плити коробчастих балок (рис. 5-б) та вузлів анкерування напружених пучків (рис. 7).

Так, для правобережної кінцевої ділянки мосту зменшення площі робочої арматури складає в найбільш пошкоджених плитах настилу до $88 \%$, в стінових панелях - до 75\%, в опорах (палях) рамної опори - до 69\%. Зменшення товщини металу опорних балок трубопроводів внаслідок корозії становить від 7\% до 19\%.

Дещо нетрадиційний метод дослідження був застосований для визначення прогинів нерозрізної прогонової будови мосту. В попередні роки було виконано кілька циклів визначення висотного положення мосту за результатами нівелювання асфальтобетонного покриття та стовпчиків бар'єрного огородження. Виконане порівняння результатів вимірювань відміток дорожнього покриття 3 аналогічними результатами 1974, 1989 та 2001 років, що отримані зі звіту [1]. Порівняльна картина відміток різних років наведена на рис. 16 .

Проте, внаслідок перекладання асфальту змінювалися позначки дорожнього покриття, а стовпчики огородження були нарощені. Тому, для уточнення результатів були додатково визначені прогини балок прогонової будови мосту шляхом нівелювання зсередини коробчастого перерізу балок. Дані нівелювання прольотних частин мосту показали, що найбільші прогини зафіксовано в прольотах між опорами 5-6, 7-8 та 10-11. Прогини в цих прольотах від 114 мм до 192 мм, в той час як в інших прольотах прогини не перевищують 64 мм. Максимальне відносне значення прогину виявлене у прольоті 5-6 і складає $(1 / 330) \times$ L. Крім того, у трьох прольотах балки Б1 та у семи прольотах балки Б2 зафіксований вигин до -88 мм.

Для всіх років, починаючи з 1989 р., зберігається загальна картина деформацій нерозрізної прогонової будови, в якій чергуються прогини і вигини сусідніх прольотів. В той же час, за результатами 1974 р. в прольотах 8-9, 9-10, 10-11 і 11-12 були зафіксовані вигини, а в 2017 р. деформації в цих же прольотах відповідають прогинам. Якісна картина зростання прогинів у інших прольотах помітна при порівнянні результатів 1989 і 2017 років. Можливо, це є наслідком тривалих процесів у нерозрізній прогоновій будові, обумовлених повзучістю бетону та релаксацією канатної арматури.

Не виключено, що значні прогини трьох прольотів мосту, що супроводжуються вигинами сусідніх прольотів, могли бути наслідком початкових неточностей профілю мосту, що виникли внаслідок відхилень при монтажі блоків та натягуванні пучків канатів. 


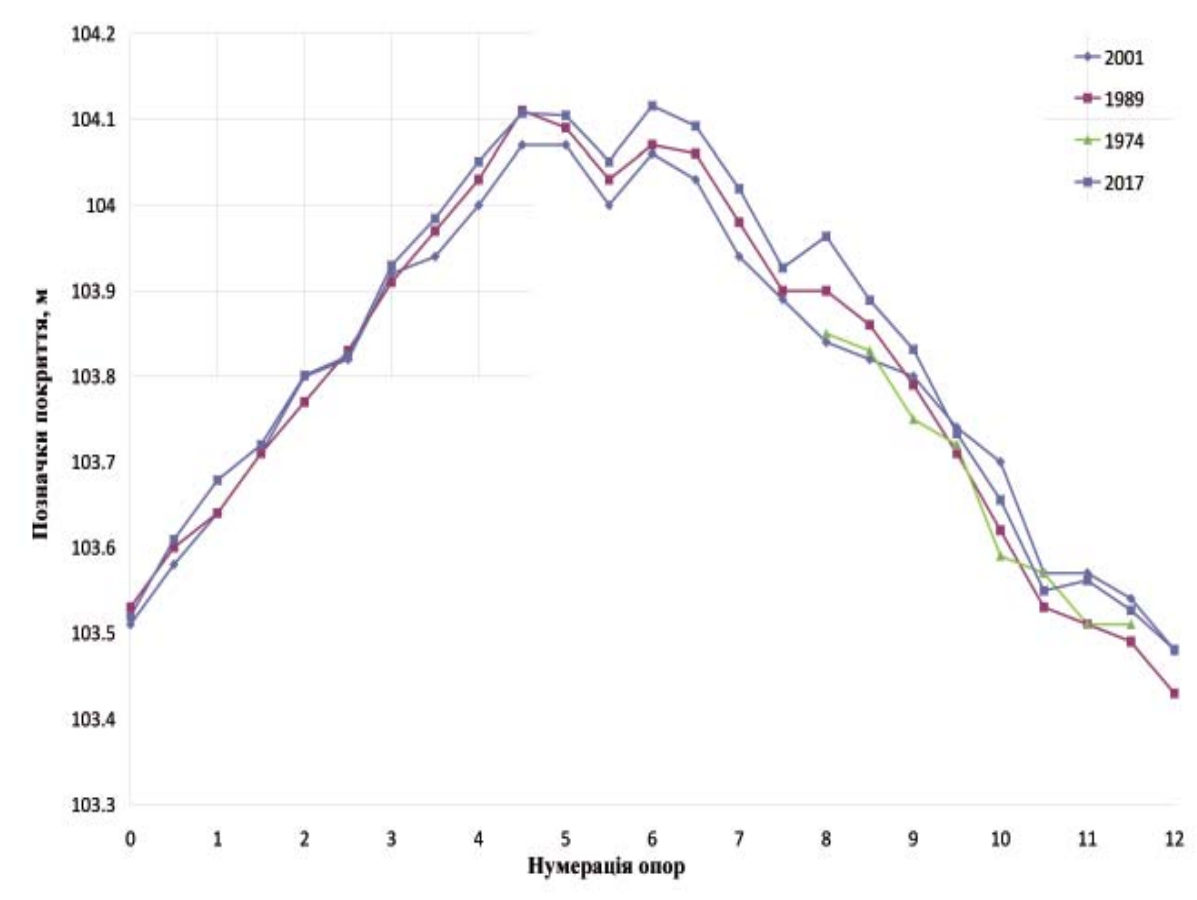

Рис. 16. Поздовжні профілі асфальтобетонного покриття по осьовій лінії мосту. Узагальнення результатів вимірювань 1989-2017 років. перерізу блоку настилу використані як розрахункові положення ДБН В.2.3-14:2006 [10], так i альтернативні розрахункові методи СНиП 2.03.01-84* [11] та ДБН В.2.6-98:2009 [12], що враховують підвищений розрахунковий опір напруженої арматури.

За результатами розрахунків рекомендовано для пошкоджених плит настилу кінцевих ділянок мосту обмежити вантажопідйомність значенням 19,5 т.

\section{ВИСНОВКИ}

Аналіз і систематизація дефектів та пошкоджень залізобетонних і металевих конструкцій мосту че-

При подальших обстеженнях прогини балок мосту рекомендовано контролювати за визначеними точками всередині прогонової будови.

Для вивчення рельєфу дна на ділянці мостового переходу було проведено проміри глибин вище та нижче вісі мосту на відстань 100 м. Побудовано профілі верхових, низових та осьового морфостворів, а також променеві морфоствори на приопорних ділянках. Незважаючи на локальні розмиви опор, загалом, в створі по осі моста, спостерігається підвищення відміток лінії дна на ділянках берегових схилів русла, в міжопорних просторах, та з боків опор.

\section{РЕЗУЛЬТАТИ РОЗРАХУНКІВ}

Розрахунки несучої здатності та вантажопідйомності виконано для конструкцій прогонової будови мосту, що мають найбільші пошкодження - блоків настилу кінцевих ділянок довжиною 15 м. Вантажопідйомність визначалась для уточнення класифікації експлуатаційного стану несучих елементів мосту. Згідно 3 технічним завданням Замовника та у відповідності до ДСТУ-Н Б В.2.3-23:2012 [7], вантажопідйомність конструкцій мосту визначалась відносно тимчасових рухомих навантажень за схемами Н-40 та Н-30.

Несуча здатність плит настилу за серією 3.503-12, випуск 16 [9] визначалася з врахуванням зменшення площі армування внаслідок корозії за результатами безпосередніх замірів діаметрів пошкоджених стержнів. Враховано, що зменшення площі поздовжнього робочого армування пошкоджених корозію плит складає в середньому $32 \%$.

Для оцінки несучої здатності нормального рез річку Десенка дозволяє зробити загальний висновок про погіршення технічного стану конструкцій мосту в порівнянні зі станом, зафіксованим при попередньому обстеженні у 2003 році [1].

Результати обстеження мосту показали, що за час, що минув після попереднього обстеження (майже чотирнадцять років), збільшився обсяг пошкоджень конструкцій. Основну небезпеку для мосту становлять прогресуючі корозійні пошкодження конструкцій, причиною яких є незадовільний стан водовідведення та гідроізоляції прогонової будови. Особливо критичним є стан паль-опор кінцевих ділянок мосту та плит настилу довжиною 15 м (на кінцевих ділянках мосту), в одній з яких виявлені розриви частини поздовжніх арматурних стержнів внаслідок корозіі. За результатами обстеження рекомендовано повністю замінити плити настилу довжиною 15 м в кінцевих ділянках мосту.

Виявлено численні пошкодження та руйнування опорних металоконструкцій комунікацій, що потребують ремонту.

Нерозрізна прогонова будова мосту має в цілому працездатний стан. Разом з тим, виявлено пошкодження окремих вузлів анкерування попередньо напружених пучків канатів внаслідок поєднання силових, динамічних та корозійних впливів. Ці пошкодження раніше не спостерігалися. Особливо небезпечними 6 прогресуючі корозійні пошкодження верхньої і нижньої плит коробчастих балок внаслідок систематичного замочування через люки у верхній плиті. Необхідно терміново забезпечити герметичність люків коробчастих балок, а також влаштувати надій-ну гідроізоляцію по їх периметру.

У попередньому звіті [1] наведено результа- 
ти хімічного аналізу зразків бетону, відібраних 3 конструкцій мосту, де зазначено, що внаслідок потрапляння солевого розчину з проїзної частини, вміст хлоридів у залізобетонних конструкціях, що постійно замочуються, значно перевищує допустимий рівень.

Разом з тим, відомо про негативний вплив хлоридів на бетон та арматуру, особливо попередньо напружену канатну, що складається з дротів малого діаметру. Так, у книзі [13] згадується про руйнування попередньо напруженої балки, що відбулося внаслідок ураження хлоридами арматурних пучків. Тому, застосування солі для боротьби з ожеледицею на мосту є недопустимим.

Залишковий ресурс елементів мосту оцінений згідно розділу 6 та Додатку Г ДСТУ-Н Б В.2.3-23:2012 [7] як прогнозований термін експлуатації від часу обстеження до настання «непрацездатного» стану (стан 5). Значення залишкового ресурсу визначене в межах від 0 років (повністю зношені окремі елементи кінцевих ділянок та мостового полотна), до 27-62 років (інші елементи). Експертна оцінка технічного стану споруди мосту, що $\epsilon$ середньозваженим значенням показників експлуатаційного стану груп конструктивних елементів, складає Е=54 бали, що відповідає загальному експлуатаційному стану 4 - «обмежено працездатний». Це обумовлює необхідність виконання таких експлуатаційних заходів: проведення обстежень за спеціальним графіком; виконання капітального ремонту; обмеження руху транспортних засобів за вагою, швидкістю та габаритними параметрами; розробка спеціальних заходів із забезпечення безаварійної експлуатації.

\section{ПЕРСПЕКТИВИ ПОДАЛЬШИХ ДОСЛІДЖЕНЬ}

Характеристики мосту через р. Десенку відповідають таким пунктам Додатка В (обов' язковий) ДБН В.1.2-5:2007 [14]: «5. Мости та штучні споруди (тунелі, шляхопроводи, естакади) на дорогах вищих категорій та швидкісних міських дорогах... 22. Об'єкти експериментального будівництва». Тому, при подальшій експлуатації мосту, а також під час розроблення проекту та виконання капітального ремонту, роботи слід проводити з науково-технічним супроводом за такими основними напрямами:

- поглиблене вивчення бібліографічних джерел щодо проектування, будівництва та експериментальних досліджень залізобетонних збірномонолітних мостових конструкцій з клеєними стиками, в тому числі - за зарубіжними джерелами, що можуть бути використані для прогнозування змін стану мосту та для вибору методів ремонтних робіт;

- спостереження за динамікою зміни прогинів коробчастих балок прогонової будови;

- спостереження за динамікою зміни ширини розкриття основних тріщин у діафрагмах прогонової будови і опорах;
- спостереження за фактичним температурним режимом прогонової будови і трубопроводів; вимірювання фактичних температурних деформацій прогонової будови і трубопроводів, визначення їх переміщень у поздовжньому i поперечному напрямках відносно осі мосту;

- перевірні розрахунки несучої здатності елементів прогонової будови та опорних конструкцій трубопроводів з врахуванням фактичного динамічного впливу;

- уточнення вантажопідйомності нерозрізної прогонової будови з врахуванням фактичного динамічного впливу;

- удосконалення методики ультразвукової діагностики клеєних швів та виконання суцільної діагностики швів прогонової будови; - розрахункова оцінка впливу стіснених поздовжніх i поперечних деформацій трубопроводів на опори мосту, вивчення можливості виникнення значних поздовжніх та/або поперечних горизонтальних зусиль на опори від деформацій трубопроводів; розрахункова перевірка тріщиностійкості збірномонолітних конструкцій опор при дії горизонтальних і вертикальних навантажень.

Для уточнення оцінок технічного стану елементів мосту та розробки рішень щодо ремонту необхідне врахування особливостей його конструктивних рішень та досвіду експлуатації аналогічних споруд.

\section{БІБАІОГРАФІЧНИЙ СПИСОК}

1. Міст через р. Десенка. Спеціальне комплексне обстеження. Технічний звіт у 5 книгах: Кінцеві ділянки мосту. Обстеження прогонових будов мосту через р. Десенка. Обстеження конструкцій (мостове полотно, опори). Узагальнення звіту. АТЗТ «Київсоюзшляхпроект»- НВФ «Мостопроект»«КиївНДАбудмост». 2001-2003.

2. Предварительно напряженный железобетон (по материалам V международного конгресса федерации по предварительно напряженным конструкциям - ФИП, Париж, 1966 г.). Г.И. Бердичевский, А.П. Васильев, А.А. Гвоздев, Е.И. Крыльцов, К.В. Михайлов. - М.: Стройиздат, 1968. - С. 143 - 186.

3. Предложения по применению мощных арматурных пучков из прядей с конусными анкерами. СОЮЗДОРНИИ. М., - 1971. (http://www. gosthelp.ru/text/Predlozheniyapoprimeneniy. html).

4. ВСН 98-74 /Минтрансстрой СССР. Технические указания по проектированию, изготовлению и монтажу составных по длине конструкций железобетонных мостов. - М., 1975.

5. Мохаммад М.Е. Условия применения составных по длине железобетонных пролетных строений автодорожных мостов в Сирийской Арабской Республике. Автореф. дис. ... канд. 
техн. наук. - M., 1992. (http://tekhnosfera.com/ view/496108/a\#?page=1).

6. Браун В.В. Параметры клееных стыков составных по длине железобетонных пролетных строений мостов из условия обеспечения прочности и долговечности. Автореф. дис. ... канд. техн. наук. - М., 1991. (http://tekhnosfera. com/view/520256/a\#?page=1).

7. Настанова 3 оцінювання i прогнозування технічного стану автодорожніх мостів: ДСТУ-Н Б В.2.3-23:2012. - [Чинний від 201312-01]. - Київ: ДП «Укрархбудінформ», 2013. - 45 с. - (Нац. стандарт України).

8. Глуховский В.П. Контроль качества заполнения трещин в бетоне с помощью ультразвука // Строительство, материаловедение, машиностоение: Сб. научних тр. - Днепропетровск: ПГАСА, 2006. - Вып. 37.

9. Типовые конструкции и детали зданий и сооружений. Серия 3.503-12. Унифицированные сборные пролетные строения из предварительно напряженного железобетона для мостов и путепроводов на автомобильных и городских дорогах. Вып. 16. Пролетные строения из пустотных плит длиной от 6 до 18 м, армированных стержневой арматурой классов A-IV и A-V. Минтрансстрой CССР. - М., 1973.

10. Мости та труби. Правила проектування: ДБН В.2.3-14:2006. - [Чинні від 2007-02-01]. - Київ, 2006. - 367 с. - (Буд. норми України).

11. СНиП 2.03.01-84* Бетонные и железобетонные конструкции (термін дії з 01.01.1986р. до 01.06.2011 р.).

12. Бетонні та залізобетонні конструкції. Основні положення: ДБН В.2.6-98:2009. - [Чинні від 2011-07-01]. - Київ, 2011. - 71 с. - (Буд. норми України).

13. Коррозия бетона и железобетона, методы их защиты В.М. Москвин, Ф.М. Иванов, С.Н. Алексеев, Е.А. Гузеев. - М.: Стройиздат, 1980. - С. 473.

14. Науково-технічний супровід будівельних об'єктів: ДБН В.1.2-5:2007. - [Чинні від 200801-01]. - Київ, 2017. - 16 с. - (Буд. норми України).

Стаття надійшла до редакції 05.09.2018 р. 